DANMARKS GEOLOGISKE UNDERS $\varnothing$ GELSE

IV. RÆKKE. BD. 4. NR. 2

GEOLOGICAL SURVEY OF DENMARK. IV. SERIES. VOL. 4 . NO. 2

\title{
Lerblokke som Bundsediment i danske Farvande
}

Af

Sigurd Hansen og Hilmar Ødum

I kommission hos

C. A. REITZELS FORLAG (JØRGEN SANDAL)

KøBENHAVN 1960 
DANMARKS GEOLOGISKE UNDERSØGELSE

IV. RÆKKE. BD. 4. NR. 2

Geological Survey of Denmark. IV. Series. Vol. 4. No. 2

\section{Lerblokke som Bundsediment i danske Farvande}

Af

Sigurd Hansen og Hilmar Ødum

I kommission hos

C. A. REITZELS FORLAG (JØRGEN SANDAL)

KØBENHAVN 1960 


\section{NDHOLD}

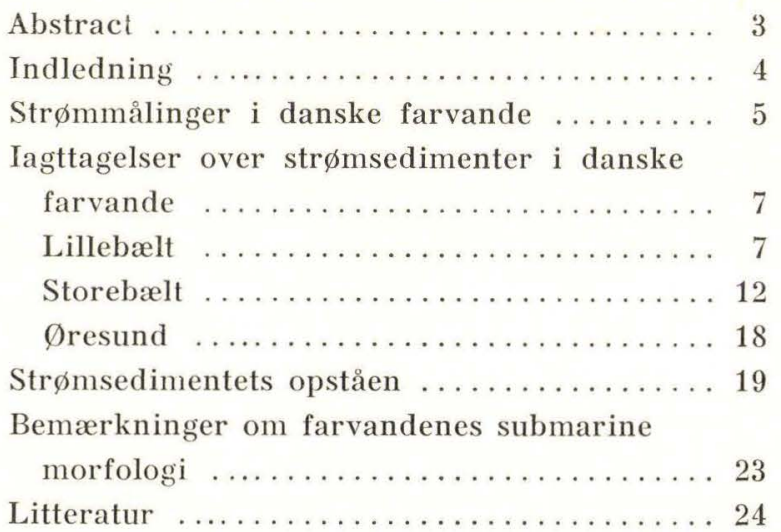




\section{Abstract \\ Clay Boulders as a Bottom Deposit in Danish Waters.}

The exchange of water between the Baltic and the ocean through the Danish Sounds gives rise to a system of currents. The individual currents are dependent on outflow, tides, meteorological factors, bottom relief, etc. The rate of the surface currents is regularly measured at the light-ships, while the rate of the bottom currents is only measured occasionally. Bottom currents are accordingly rather unknown, and few average velocities have been published.

The present paper deals with a particular bottom deposit observed in Danish Sounds. It consists of large lumps or »boulders of clay (e. g. Tertiary clay, Interglacial clay or Glacial till) embedded in normal marine sand and gravel. A »clay boulder « conglomerate of this kind was exposed for a short time at the bottom of the Lillebælt during the construction of the Lillebælt Bridge (fig. 1). The sclay boulders w were in this case derived from the Tertiary Lillebælt clay.

Recent investigations of the Storebælt and The Sound with the Kullenberg Piston Core Sampler revealed that a similar sediment is found also in these areas. However, the cores generally display alternation of glacial till and marine shell bearing sand, because the diameter of the Piston Corer is smaller than that of the majority of the »till boulders «. (fig. 2).

The clay boulder conglomerates on the present sea bottom of the Danish Straits are evidence of rather strong submarine erosion and redeposition. It is suggested that erosion is particularly efficient along the submarine channels, and that the deep hollows are mainly due to submarine erosion. 


\section{Indledning}

På søkort angives i reglen bundforhold: ler, dynd, sand, sten o.s. v., og søkortet kan altså i en vis forstand opfattes som et jordbundskort. Der er imidlertid en væsentlig forskel på s $\varnothing$ kortets angivelser og angivelserne af jordarter på kort fra land: søkortets angivelser er overfladiske i virkelig forstand, omfatter kun det allerøverste lag, ofte kun få $\mathrm{cm}$; landkortets angivelser er dybere găende, hvad enten der er tale om »jordbundskort" i landbrugsmæssig forstand (eller til andre, specielle formål) eller »geologiske kort «, hvor jordarternes genese er lagt til grund (moræneler, smeltevandssand o. s. v.). Søkortets angivelse af sand eller dynd kan i givet fald blot omfatte et tyndt overtræk, svarende til, om man på et geologisk kort ville angive et decimetertyndt slør af flyvesand uden at omtale, at der under dette kunne skjule sig vidt forskellige aflejringer.

På nutidig havbund kommer næppe andre kræfter i funktion end strøm og bølgeslag. Af disse må på dybere vand strømmen formodes at være hovedfaktor; på dybere vand, udenfor kystzonen, må bølgebevægelsens rolle væsentlig være at »lette det materiale, strømmen i $\varnothing$ vrigt flytter og aflejrer. Resultatet af bundstrømmens arbejde kan spænde fra »renskyllet bund " (hård bund, fast ler, efterladte sten) til sand og slam. 


\section{Strommålinger i danske farvande}

Systematiske målinger af strømstyrken i danske farvande, og undersøgelser over relationen mellem strømstyrke og bundforhold, foreligger kun i ringe udstrækning. Målinger af strømforhold $\mathrm{m}$. m. er udført som led i byggeforetagenders projektering, og de er da ofte knyttet til byggeforetagender ved kysten, - altså stærkt lokalt begrænsede.

Forud for Lillebæltsbroens bygning foretoges i 1923-24 strømmålinger i bæltet, publiceret af Svend Brannov (1925). Heraf fremgår som et hovedtræk, at overfladestrøm næsten altid er langt stærkere end bundstr $\varnothing \mathrm{m}$; begge er dog meget varierende både i styrke og retning (ud- og indgående $s t r \phi m)$. Som eksempel anfører BRANNov overfladestrøm på $190 \mathrm{~cm} / \mathrm{sec}$. og samtidig bundstr $\varnothing \mathrm{m}$ på $70 \mathrm{~cm} / \mathrm{sec}$; af hans diagrammer ses iøvrigt hyppigt overfladestrøm på over $100 \mathrm{~cm} / \mathrm{sec}$. og samtidig bundstrøm 0 i 40 m dybde. - Den stærkeste målte overfladestrøm havde en hastighed af $325 \mathrm{~cm} / \mathrm{sec}$; den stærkeste målte bundstrøm var i $20 \mathrm{~m}$ dybde $170 \mathrm{~cm} / \mathrm{sec}$, i $40 \mathrm{~m}$ dybde $110 \mathrm{~cm} / \mathrm{sec}$. (NB ikke samtidige målinger).

Målinger af strømretninger og strømstyrker udføres iøvrigt løbende af Meteonologisk Institut ved følgende fyrskibe indenfor de her behandlede farvande: Lappegrund, Halskov Rev (og Kattegat SW = Schultz's Grund), og resultaterne offentligg $\varnothing$ res af instituttet i Nautisk Meteorologisk Årbog. Disse regelmæssigt udførte målinger gælder dog kun overfladestrømmen. De maksimale tal pr. måned ligger for de to førstnævnte fyrskibe hyppigt mellem $3 \mathrm{og} 4 \mathrm{knob}$ (ca. 150-200 $\mathrm{cm} / \mathrm{sec}$.), men kan være væsentlig mindre.

Desværre udføres målinger af strømmens styrke i dybere niveauer (indtil 15 eller 20 (23) $\mathrm{m}$ dybde) kun i kortere perioder med særlig anledning. Sådanne målinger udførte før 1925 er udførligt behandlede af J. P. JacoBsen (1925). Hans tabeller giver fortrinsvis måneds- eller døgnmiddeltal og bekræfter i mange henseender det billede af stadig i tid og retning vekslende str $\emptyset \mathrm{m}$, og meget forskellige str $\emptyset$ mstyrker i forskellig dybde, som fremkom ved BRAn novs unders $\varnothing$ gelse i Lillebælt. Groft regnet er strømstyrken aftagende mod dybden og f. eks. ved Lappegrund Fyrskib passerer strømstyrkeværdien meget hyppigt nul (teoretisk) i et vist dybdeniveau, således at man derunder har modsat rettet strøm, men dog næsten altid med mindre strømstyrke end overfladestr $\varnothing$ mmen. Fra JACOBsens tabel 1 kan eksempelvis anf $\varnothing$ res: 
Lappegrund Fyrskib 1914. Dognmiddelvardier.

$\begin{array}{rcccc} & \begin{array}{c}\text { Overflade- } \\ \text { strømhast. } \\ \mathrm{cm} / \mathrm{sec} .\end{array} & \text { Retning } & \begin{array}{c}\text { Bund- }(23 \mathrm{~m}) \\ \text { strømhast. } \\ \mathrm{cm} / \mathrm{sec} .\end{array} & \text { Retning } \\ 9 / 5 \ldots \ldots \ldots & 107 & \text { nordg. } & 0 & - \\ 16 / 5 \ldots \ldots \ldots & 109 & \text { nordg. } & 6 & \text { nordg. } \\ 19 / 5 \ldots \ldots \ldots & 10 & \text { sydg. } & 27 & \text { sydg. } \\ 23 / 5 \ldots \ldots \ldots & 126 & \text { nordg. } & 0 & - \\ 28 / 5 \ldots \ldots \ldots & 138 & \text { nordg. } & 2 & \text { sydg. } \\ 8 / 6 \ldots \ldots \ldots & 156 & \text { nordg. } & 8 & \text { sydg. } \\ 9 / 6 \ldots \ldots & 180 & \text { nordg. } & 9 & \text { sydg. }\end{array}$

Den 19. maj har overflade- og bundstrømmen haft samme retning, men bundstrømmen været stærkest; man må dog ikke opfatte disse døgnmiddelværdier som øjebliksbilleder af strømforholdene.

Siden JacoBsens arbejde fremkom (1925) har der i en del af august måned 1931 været udf $\varnothing$ rt strømmålinger i større dybder ved Lappegrund og Halskov Revs fyrskibe, begge steder til $20 \mathrm{~m}$ dybde (Bulletin Hydrographique 1931, Appendix). Ved Lappegrund måltes maximalværdien i $20 \mathrm{~m}$ dybde til $113 \mathrm{~cm} / \mathrm{sec}$. (sydgående) og ved Halskov Rev til $120 \mathrm{~cm} /$ sec. (sydgående); begge steder 8 . august. De nyeste målinger ${ }^{*}$ ) er udførte af Meteonologisk Institut ved Lappegrund i november 1956-november 1957, hvor st $\varnothing$ rste måledybde var $15 \mathrm{~m}$ (fyrskibet flyttet siden 1914) og den maximale målte strømstyrkeværdi i denne dybde var $141 \mathrm{~cm} / \mathrm{sec}$. (sydgående str $\varnothing \mathrm{m}$ den 28. november 1957).

Desværre har man ved alle disse målinger af strømhastigheder i de st $\varnothing$ rre dybder $(15,20$ og $23 \mathrm{~m})$ ingen angivelse af bunddybden på det pågældende sted og tidspunkt, således at det fra geologisk synspunkt interessante spørgsmål om sammenhængen mellem bundrelief og strømstyrke kunne belyses. Almindeligvis antages, at strømstyrken hæmmes meget stærkt nær bunden, og BRAN Novs diagrammer over strømfordeling i Lillebælt efter dybde og tid (Brannov 1925, fig. 16 og 17) viser da ogsă kun en enkelt afvigelse fra denne regel, betinget af et strømskifte fra nordgående til sydgående strøm og af mindre end 1 times varighed.

Alle disse værdier er dog middelværdier for enkelte d $\phi g n$. Det citerede arbejde (JACOBSEN 1925) havde til formål at belyse vandomsætningen mellem Østers $\varnothing$ og Kattegat gennem bælter og sunde, ikke at meddele strømforhold som $\emptyset$ jebliksiagttagelser. Set fra et geologisk synspunkt er det klart, at middelværdier ikke giver fuld oplysning om strømmens virkelige transportevne.

De forhold, der i denne forbindelse har størst interesse, nemlig 1) størrelsen af de virkelige, maximale strømstyrker umiddelbart ved bunden, samt 2) varighed og 3) hyppighed af de mere ekstreme strømstyrker samt endelig 4) den helt lokale sammenhæng mellem disse stærkere strømforhold og bundrelieffet belyses kun i ringe grad af det foreliggende målemateriale. Det må nemlig være disse fire faktorer, der er bestemmende for bundstrømmenes erosions- (løsbrydnings-) evne og transportevne.

*) For oplysninger og orientering er vi cand. mag. E. F. Hermann, Danmarks Fiskeri- og Havundersøgelser, Charlottenlund, megen tak skyldig. 


\section{Iagttagelser over strømsedimenter i danske farvande}

Vi skal her fremlægge nogle iagttagelser over bundstr $\varnothing \mathrm{mmens}$ virkning i danske farvande.

\section{Lillebælt.}

Ved anbringelsen af Lillebæltsbroens piller i 1932 gaves der ved udgravningen af arbejdskamrene i pillernes bund en usædvanlig lejlighed til direkte iagttagelse af snit gennem bundens lag (D. S. B. Lillebæltsbroen). Arbejdspladsen for pille IV besøgtes af os begge. Sigurd Hansen har beskrevet sine iagttagelser i sin dagbog, hvoraf f $\varnothing$ lgende kan anf $\varnothing$ res:

»Efter aftale besøgte undertegnede d. 13. og 14. april 1932 broarbejderne ved Snogh $\varnothing$ j for under udgravningsarbejderne i bunden af pille IV (135 $\mathrm{m}$ fra Jyllandssiden) at foretage en geologisk besigtigelse af de $\mathrm{i}$ arbejdskammeret blottede profiler i Lillebæltsler og de derovenpå hvilende havbundslag.

Ved besøget d. 13. var der i arbejdskammerets $\phi$ stlige halvdel udgravet en nord-syd gående tværgrav af $4-6 \mathrm{~m}$ bredde og ca. $3 \mathrm{~m}$ dybde under kammerets loft, som iøvrigt hvilede på selve havbunden. Mod фst var dette rum begrænset af en ca. $20 \mathrm{~m}$ lang og indtil $3 \mathrm{~m} \mathrm{~h} \phi \mathrm{j}$, ligeledes nordsyd gảende profilvæg, af hvis sydende der i fig. 1 er gengivet en meget skematisk skitse, og til hvilken mine iagttagelser væsentlig er knyttede. Havbunden her ligger efter angivelse ved kote ca. $\div 21 \mathrm{~m}$ og udgravningens bund således ved ca. $\div 24 \mathrm{~m}$. - Det var dog særlig den sydlige halvdel af den omtalte profilvæg, der blev gjort til genstand for undersøgelse og prøveudtagning, da betonst $\varnothing$ bningen allerede var påbegyndt i den omtalte udgravnings nordlige del.

Lagene i profilvæggen viste intet som helst vidnesbyrd om nogen påvirkning eller forstyrrelse forårsagede ved pillens nedsætning på havbunden. Over st $\varnothing$ rstedelen af arbejdskammerets areal, syntes dettes loft at hvile direkte på havbundsaflejringerne, kun sydligst $i$ den her beskrevne profilvæg (altså i pillens sydøsthjørne) var der et lille areal med luft mellem kammerets loft og havbunden.

Øverst i profilvæggen (fig. 1) træffes en lille lagserie A på ialt 12-15 cm tykkelse bestående af mere normalt udseende havbundslag, nemlig $\emptyset$ verst et 1-2 $\mathrm{cm}$ tykt lag af sort, tangholdigt, fint sand og derunder et 


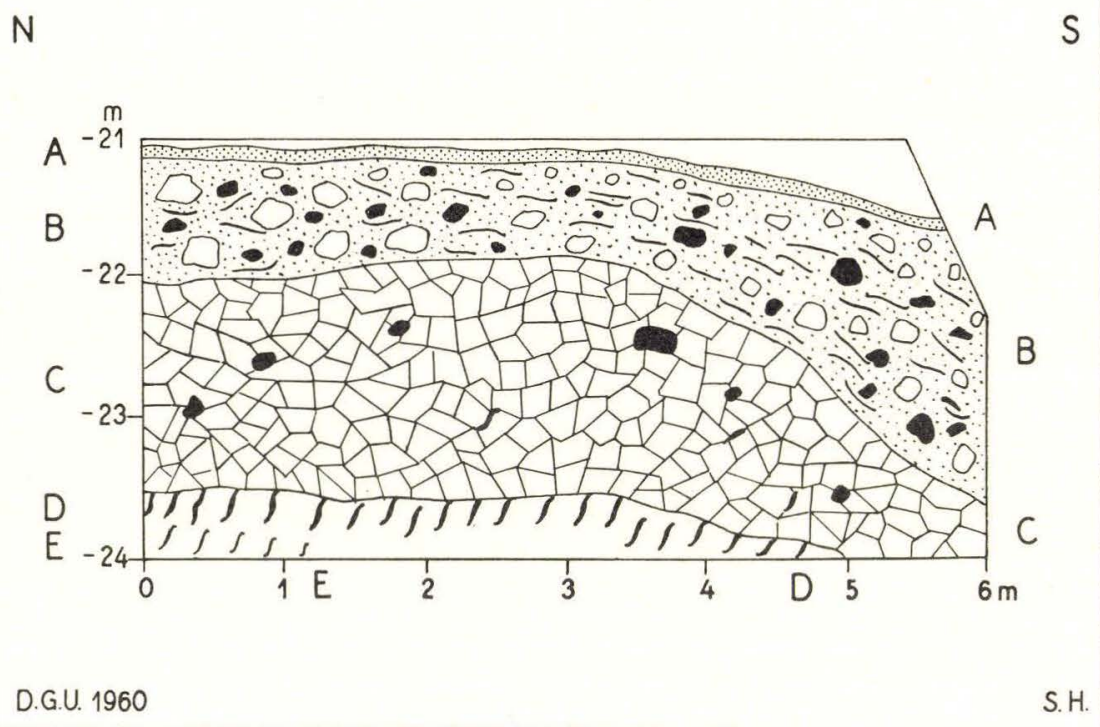

Fig. 1. Lillebælt. Skematisk skitse af profilvæggen i udgravning til bropille IV. Den vandrette linje $(\div 21 \mathrm{~m})$ repræsenterer arbejdskamrets loft. Lagene $\mathrm{A}-\mathrm{C}$ udgør de løse aflejringer på havbunden (se beskrivelse s. $7 \mathrm{flg}$.), D og E det faststående Lillebæltsler. Prikker: sand; sort: sten; hvide omrids: rulleblokke af Lillebæltsler. Sandovertrækket på lerblokkene i lag C, samt små ansamlinger af sand i dette lag er ikke søgt fremstillet.

Section through the bottom deposits of Lillebalt, measured during excavation for pier no. IV of the Lillebælt-bridge 1932. 21-24 m below sea-level. Dotted: Marine sand; black: boulders of granite etc.; white: Tertiary clay. A: Top layer of sand. B: Sand with boulders of granite and rounded boulders of clay. C: Deposit of rolled boulders of Tertiary clay, coated with sand and packed together; isolated granite-boulders. D: Tertiary clay in situ (with bore-holes of Mya and Pholas).

8-12 cm tykt lag af ret groft, gråt, velsorteret sand med ganske enkelte sten og skaller. Nogle af disse skaller (Mya truncata) liggende nederst i laget vender ydersiderne opad, medens der ind under skallernes hulhed er uudfyldte små rum. Lagserien A afsluttes nedadtil med et nyt tangblandet, sort sandlag på et par $\mathrm{cm}$ tykkelse.

Lagserien A's karakter og indhold af skaller viser, at det drejer sig om en meget almindelig type på en marin aflejring. De omtalte skallers uudfyldte rum og andre træk ved lagserien viser, at den er af rent recent alder, måske kun nogle få år gammel. - På den anden side viste de nylig d $\varnothing$ de muslinger, som sad fæstnede nede i sandet i den stilling, de indtager i levende live, med ånderør op til havbunden, at vi har med overfladen af jordlagene at gøre, som den var, før sænkekassen begyndte at røre bunden, med andre ord, at sænkekassen eller pillen på dette sted ikke har forårsaget nogen forandring af bundens lag.

La g B består overvejende af groft, marint sand, der ikke alene er yderst 
lidt sorteret, men tilmed indeholder ret store mængder af muslingeskaller (Mya truncata, Tapes pullastra, Saxicava arctica), som dels ligger fuldstændig spredte, dels ligger samlede i antydninger til skallag. Ydermere ligger der i laget en del ret store sten, som synes at opnả størrelser på 30-40 cm. Også disse sten kan ligge således, at de kan vise antydning til et stenlag, men i hovedsagen ligger de uregelmæssigt spredt. Stenene bærer mærker af, at balaner og andre marine dyr har siddet fæstnede på dem. En tredie indblanding i Lag B's grove sand udgøres af klumper af Lillebæltsler, som $\emptyset$ verst i laget er noget mindre talrigt til stede, af mindre størrelse (f. eks. 3-6 cm tværmål) og med en noget afrundet form, som vidner om, at de har været rullede. I den nedre del af lag B tiltager disse klumper stærkt i antal, ligesom de også der kan opnå væsentlig st $\varnothing$ rre diameter $(6-10 \mathrm{~cm})$. Tykkelsen af lag B er længst mod syd i profilvæggen indtil $1,5 \mathrm{~m}$, medens den nordligere synes at være meget mindre.

Trods det, at der ikke er nogen som helst tvivl om lag B's marine oprindelse, må det dog fremhæves, at lagets karakter er noget usædvanligt for et vandaflejret sediment. En så temmelig regellø̆s blanding af stǿrre og mindre enheder (kornstørrelser) imellem hinanden som den, der ses i lag B, træffer man almindeligvis kun, hvor der er tale om moræneaflejringer eller aflejringer fra en vildbæk. Denne vanskelighed ved tydningen kan imidlertid have sin naturlige årsag deri, at det geologiske kendskab til de marine bundstrømmes aflejringsmåde og фvrige forhold er ret ringe.

Lag C. Grænsen mellem aflejringerne B og C er ikke skarp, men overgangen mellem de to dannelser sker ganske jævnt. Lag $\mathrm{C}$ er særlig karakteriseret ved at bestå af stø̆re og mindre brokker af Lillebæltsler, der ligger så tæt og fast sammen, at man ved første flygtige besigtigelse antager laget for at være det faste og intakte Lillebæltsler, stående i en væg med overfladiske forureninger af grovere sand. En nøjere undersøgelse viser dog, at forureningen med sand er gennemgående, og at dette sand indeholder enkelte muslingeskaller og endnu hyppigere fragmenter af sådanne, hvoraf fremgår, at det forurenede sand er marint og postglacialt ligesom sandaflejringen i lag B. - Den måde, hvorpå dette sand forekommer ned mellem de i det indre rene lerbrokker og ofte omgivende selv st $\varnothing$ rre lerbrokker med et helt overtræk på alle ydersiderne viser, at laget $\mathrm{C}$ i virkeligheden er en ung (postglacial eller recent) aflejring af løsbrudte brokker af Lillebæltsler, der under transporten på bæltets bund eller ved aflejringen er blevne bestrøede med eller »indsyltede $i$ « det marine sand. Disse brokker eller klumper af Lillebæltsler har bevaret en meget kantet, uregelmæssig ydre form, er altså i meget mindre grad rullede og rundslidte end de lerklumper, der findes i den $\varnothing$ vre del af lag B.

Rigtigheden af tydningen af lag $\mathrm{C}$ som bestående af løsbrudte og nyaflejrede klumper bekræftes også ved en biologisk iagttagelse. I et par tilfælde konstateredes det nemlig, at lagets lerklumper var gennemborede af et fingertykt rør boret af en boremusling, og at borer $\phi r e t$ nu lå i vandret stilling. Borerøret kan i denne stilling umuligt være boret af muslingen, men lerklumpen må bevisligt være flyttet og drejet, siden dyret 
levede i borehullet. - Lag C's tykkelse synes i nærværende profilvæg at variere mellem $1 / 2$ og $1 \frac{1}{2} \mathrm{~m}$. - Arbejderne angav, at nogle af de på udgravningens bund liggende større sten skulle hidrøre fra lag $\mathrm{C}$, men selv så jeg kun mindre - til ægstore - sten i dette lag.

Lag D. Det nederste synlige lag (eller rettere horisont) i profilvaggen er D, der viser sig at være Lillebæltsler på primært lejested, men kun for så vidt intakt, som det ikke er løsrevet fra forbindelsen med de underliggende lag, men nok i ringe grad forurenet med sand, der imidlertid kun optræder som udfyldninger i de borerør og andre udhulninger, som muslinger og andre organismer har udarbejdet i leret. Sandudfyldningerne er tydeligvis af samme marine oprindelse, som sandet mellem brokkerne i lag C og som sandlagene i B, idet det på samme måde indeholder skalstumper og skalgrusmel som disse dannelser. - Organismerne, der har bearbejdet lag $\mathrm{D}$, kan imidlertid kun have levet i en periode, da lagene $\mathrm{A}, \mathrm{B}$ og $\mathrm{C}$ var fravarende, og at der $\mathrm{i}$ forholdsvis ung tid (den marine periode på stedet) har været et tidsrum, hvor grænsen mellem C og D udgjorde bæltets bund, fremgår med al ønskelig tydelighed deraf, at de pågældende organismer næppe kan udstrække deres virksomhed til større dybde end 1/3-1/2 $\mathrm{m}$ under havbunden, medens der i nærværende profilvæg endnu i dybde af $3 \mathrm{~m}$ under havbunden var ret talrige spor af deres gravende eller borende virksomhed. -

Grænsen mellem lag C og D syntes heller ikke at kunne fastlægges med absolut nøjagtighed uden meget indgånde detailiagttagelser, men indenfor $1 \mathrm{dm}$ spillerum kan man dog nok angive den.

Lag E, det absolut uberørte Lillebæltsler, var overhovedet ikke synlig i den pågældende udgravning, idet borerørsudfyldningerne kunne følges helt ned i udgravningens bund, men formodentlig ville E kunne være nået ved gravning ganske tat under udgravningens bund.

Ved bes $\emptyset$ get i pillen torsdag d. 14. april var profilet i pillens $\varnothing$ stende næsten utilgængeligt, men til gengæld var der på tilsvarende sted i pillens vestlige halvdel foretaget en ny udgravning. Vestvæggen i denne var let tilgængelig og nåede i midten 1,90 $\mathrm{m}$ højde. Iagttagelserne og prøveudtagningen skete særlig i midten af dette profil.

Det mest iøjnefaldende ved profilvæggen her i vestenden af pillen er en nyfyldning af indtil $0,45 \mathrm{~m}$ mægtighed, der er indskudt mellem den oprindelige ægte havbund (repræsenteret af lag A's overkant med isiddende kvalte muslinger (Mya truncata) og arbejdskammerets loft. Bortset fra dette ekstra lag, er lagrækken den samme som i profilet i pillens ǿstlige ende, kun er magtigheden af lagene $\mathrm{A}, \mathrm{B}$ og $\mathrm{C}$ (altså de »løse « lag) væsentlig mindre, tilsammen kun $3 / 1-1 \mathrm{~m}$, medens de samme lag i sydenden af profilet $\mathrm{i}$ pillens $\phi$ stende tilsammen når over 2 eller måske $2 \frac{1}{2}$ m. Lag A er kun få cm tykt, lag B 12-15 cm tykt og lag C, der ikke kan afgrænses helt nøjagtigt opad og nedad på grund af jævne overgange, har en mægtighed på indtil godt $1 / 2 \mathrm{~m}$. Ganske de samme ræsonnementer om lagenes dannelsesmåde og alder kan gennemføres for dette profil som for det i pillens $\varnothing$ stende.

Om måden, hvorpå nyfyldningen mellem arbejdskammerets loft og den oprindelige havbund var kommet til stede, var der først nogen tvivl. 
Den forklaring, at sænkekassen eller pillen ved en ensidig første berøring af bunden skulle have presset nyfyldningsmassen, der bestod af en lignende materialeblanding som lag B med et rigeligt antal af lerklumper, ind over havbunden i midten af pillerummet, syntes ikke mulig, da man ikke derved ville være i stand til at tænke sig laget $\mathrm{A}$ og havbunden forblive liggende så uforstyrret, som de faktisk gjorde. - - Imidlertid gav baneingeniør Muxch-Petersen mig en oplysning, der synes at få væesentlig betydning for en rigtig tydning af denne nyfyldning. Baneingeniøren meddelte nemlig, at der i et par dage efter at sænkekassen var kommet til at røre bunden, havde hersket en stærk nordgående strøm, som havde eroderet på bunden, således at fornyede pejlinger af havbunden omkring pillen havde vist en udgravning eller bortfjernelse af indtil 2,5 m materiale ved sænkekassens sydvestlige hjørne. Da det mentes, at sænkekassens rø̆rkrans på dette tidspunkt endnu ikke sluttede fast til bunden på det pågældende sted, bliver den rimeligste tydning den, at det nyaflejrede lag inde $\mathrm{i}$ arbejdskammeret simpelt hen repræsenterer en del af det fra »udkolkningen « bortgravede materiale som en ny bundstromsaflejret dannelse.

En betragtning af denne nyaflejring, sảledes som den er opbygget af en regell $\varnothing$ s blanding af strandsten, skaller, lerklumper og sand, liggende uden nogen antydning af sædvanlig vandsortering, fører da til, at man også bedre kan forlige sig med opfattelsen af lag B og C i vægprofilerne, hvilke jo i deres opbygning viser en lignende regelløshed, som værende aflejringer af bundstrømme.

De fleste af de slutninger, som kan uddrages af de direkte iagttagelser af bundlagene, er indflettede $\mathrm{i}$ den ovenfor givne beskrivelse af profilerne; de skal derfor kun kort resumeres her til slut:

1) Lagene $\mathrm{A}, \mathrm{B} \circ \mathrm{g} \mathrm{C}$, hvoraf $\mathrm{C}$ overvejende består af løsbrudte og nyaflejrede klumper og brokker af Lillebæltsler, må anses for at være aflejrede af marine bundstrømme i geologisk set meget ung tid.

2) Inden lagene $\mathrm{A}, \mathrm{B}$ og $\mathrm{C}$ her på stedet kom til aflejring, har bæltets bund en tid ligget ved græensen mellem C og D, og i denue periode blev leret i horisont D, der iøvrigt består af uomlejret Lillebæltsler, gennemboret af boremuslingens (Pholas candida) rør, hvilke r $\phi \mathbf{r}$ senere blev udfyldt af marint sand, som det, der danner hovedparten af lag $B$.

3) De løse havbundsaflejringer (A, B og C) veksler indenfor pille IV's område fra $3 \frac{3}{4}$ til ca. $2 \frac{1}{2} \mathrm{~m}$ i samlet tykkelse.

4) Den ved forundersøgelserne målte stærkeste bundstrøm pả $20 \mathrm{~m}$ vand havde en hastighed på $170 \mathrm{~cm} / \mathrm{sec}$. (Brannov 1925). Denne strømstyrke skulle efter iagttagelser i floder kun kunne flytte sten af størrelse mellem duexg $\left(145 \mathrm{~cm} / \mathrm{sec}\right.$.) og $5 \mathrm{dm}^{3}(227 \mathrm{~cm} / \mathrm{sec}$.). De i lag B observerede sten synes at nå mindst $10 \mathrm{dm}^{3} \mathrm{i}$ st $\phi$ rrelse. Til at flytte disse skulle efter flodiagttagelserne formodentlig kræves en strømstyrke på omkring $250 \mathrm{~cm} / \mathrm{sec}$. (HЈulström, 1935). 
5) De hvirvelagtige bundstrømme, der fremkaldes eller forstærkes af bropillernes tilstedeværelse, vil utvivlsomt være i stand til at fjerne de løse havbundsaflejringer (lagene $\mathrm{A}+\mathrm{B}+\mathrm{C}$ ) omkring en bropille, såfremt der ikke træffes særlige foranstaltninger derimod. Formodentlig vil der også være mulighed for, at bundstrømmene (særlig i deres forstærkede form omkring en bropille) vil kunne fjerne dele af laget $\mathrm{D}$, som vil være noget svækket ved boremuslingernes tidligere angreb. Lag E eller det absolut uber $\varnothing$ rte Lillebæltsler vil formodentlig først kunne blive genstand for erosion, når det ved at ligge fremme i havbunden med fri overflade en tid lang er blevet svækket ved boremuslingernes fornyede borende virkning. - Tilstedeværelsen af lerklumperne i både lag $\mathrm{B}$ og $\mathrm{C}$ viser jo, at en sådan langsom bortgravning af Lillebæltsleret må finde sted på visse steder og til visse tider i bæltet; der findes jo nemlig ingen kystklinter med Lillebæltsler i nærheden, hvorfra klumperne kunne hidrøre. - - «

\section{Storebælt.}

I årene 1953-59 har D. G. U. udført boringer i Storebælt, dels for Kommissionen ANGÅENDE EN STOREB ÆLLTSBro (Kommissionen, 1956, bilag 12), dels som led i D. G. U.s systematiske farvandsundersøgelser (ØDum 1951). Ved velvilje fra Dan marks Fiskeri- og Havunders $\varnothing$ gelser udf $\varnothing$ res arbejdet fra $\mathrm{S} / \mathrm{S}$ »Biologen «, og boringerne foretages med »Kullenbergs Bor « (»Kullenbergs kolvlod«, »The Piston Core Sampler«); i arbejderne har bl. a. deltaget begge nærværende forfattere og Harald Krog.

Nogle boreprofiler skal gengives her. Hver boring er angivet først ved et nummer, dernæst dens position på Decca-kort og sluttelig vanddybden. Oplysningerne om boreresultaterne støtter sig overvejende på iagttagelser foretaget under borearbejdet på skibet.

De første tre boreprofiler hidrører fra punkter i den påtænkte brolinie fra Halsskov over Sprog $\varnothing$ til Knudshoved og udtoges i dagene 24/9-26/9 1953 i samarbejde med den nævnte kommision.

83 b. Position rød G 9.36 - gr $\varnothing$ n D 41.03. Vanddybde $31 \mathrm{~m}$. På østsiden af Østre Rende ud for Halsskov.

0-ca. $20 \mathrm{~cm}$ : moræneler, gråt. ca. 20-ca. 25 - : grus, groft, marint med skalstumper.

83 c. Position r $\varnothing$ d G 9.32 - grøn D 40.98. Vanddybde $29.5 \mathrm{~m}$. På østsiden af Østre Rende ud for Halsskov.

0 - $3 \mathrm{~cm}$ : marine skaller.

$3-10$ - : leret, groft, marint sand.

$10-31$ - : gråt, uforvitret moræneler.

$31-34$ - : marint, leret sand.

34 - 49 - : gråt, uforvitret moræneler.

$49-55$ - : groft, marint sand.

$55-66$ - : gråt, uforvitret moræneler.

$66-68$ - : grus. 
68- $76 \mathrm{~cm}$ : gråt, uforvitret moræneler.

$76-86$ - : marint, leret sand.

86-102 - : gråt, uforvitret moræneler.

86 a. Position r $\varnothing$ d F 22.83 - grøn E 31.74 . Vanddybde 27.5 m.

I Vestre Rende ud for Knudshoved.

0-40 $\mathrm{cm}$ : marint sand, nederst stærkt lerblandet.

40-46 - : gråt, uforvitret moræneler.

46-49 - : lerblandet, marint sand.

$49-55$ - : gråt, uforvitret moræneler.

55-58 - : lerblandet, marint sand.

58-75 - : gråt, uforvitret moræneler (muligvis den faste moræne).

92. Position gr $\varnothing n$ E 32.56 - r $\phi$ d F 20.96. Vanddybde $24.5 \mathrm{~m}$.

Vestskråningen af Vestre Rende. 7/10 1954.

0-ca. $10 \mathrm{~cm}$ : sand, fint, gråt, marint.

ca. 10-ca. 22 - : sand og grus, leret og gytjeholdigt med sten på indtil ca. $2 \mathrm{~cm}$; farve mørkegrå; gytjeindhold aftagende nedefter.

ca. 22-ca. 36 - : sand, gråt, groft, noget leret, marint med skalstumper.

ca. 36- 42 - : moræeneler, gråbrunt, uforvitret.

$42-43$ - : sand, mellemkornet, gråt, marint m. skalstumper.

43-ca. 48 - : moræneler, gråbrunt, uforvitret.

ca. 48-ca. 54 - : sand, grăt, finkornet, marint med skaller og skalstumper.

ca. 54 ca. 62 - : moræneler, gråbrunt, uforvitret.

118. Position rød E 22.46 - grøn C 38.42. Vanddybde 13.5 m.

Ca. $4 \mathrm{~km}$ vest for Reers $\varnothing \mathrm{s}$ NV-pynt. - 6/9 1955.

0-42 cm: moræeneler, gråblăt, småstenet.

42-62 - : blanding af blågrå morænelersklumper og groft sand, mere eller mindre sammenrullet, så hovedindholdet bliver sandet-gruset ler (men mere vandholdigt end lagene over og under).

62-90 - : moræneler, gråblåt, småstenet.

125. Position r $\phi$ d E 0.27 - grøn C 36.16. Vanddybde 18 m.

Midt i nordlige Storebælt mellem Hindsholm og Jammerlands Bugt, tæt $\varnothing$ st for den dybe rende, på plateauet mellem denne og Lysegrunde. - 6/9 1955 .

0-20 cm: moræneler, blågrăt, som klumper, og en mellemzone af finsand, olivengrågrønt, gytjeholdigt og med Cardiumskaller; har karakter af omskyllede morænelersklumper.

134. Position rød E 13.88 - grøn D 33.04. Vanddybde 19 m.

Ca. $4 \mathrm{~km} \mathrm{~S} \mathrm{t.} \emptyset$ for Roms $\varnothing$. - 26/9 1956.

$0-$ ca. $215 \mathrm{~cm}$ : ler og gytje, olivengr $\varnothing \mathrm{nt}$, marint med vekslende sandindhold og indhold af skaller. 


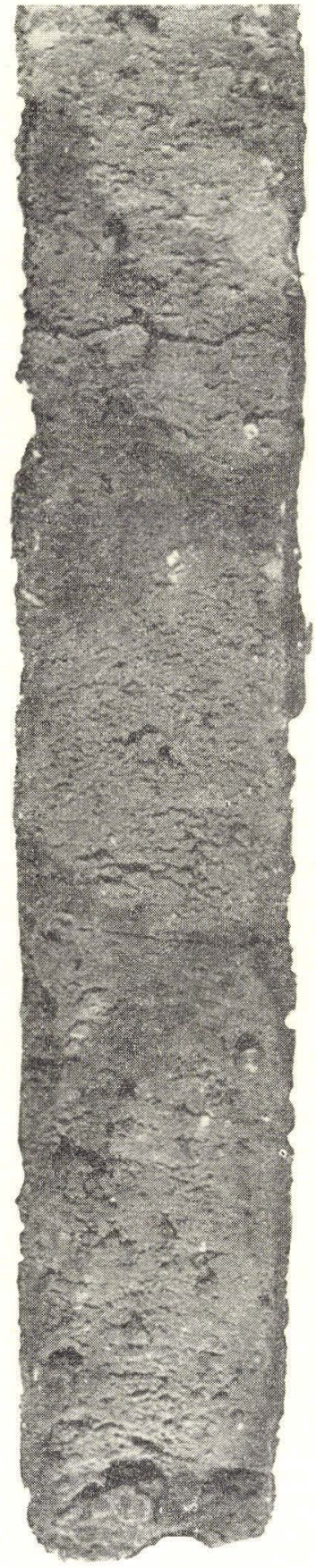

a.

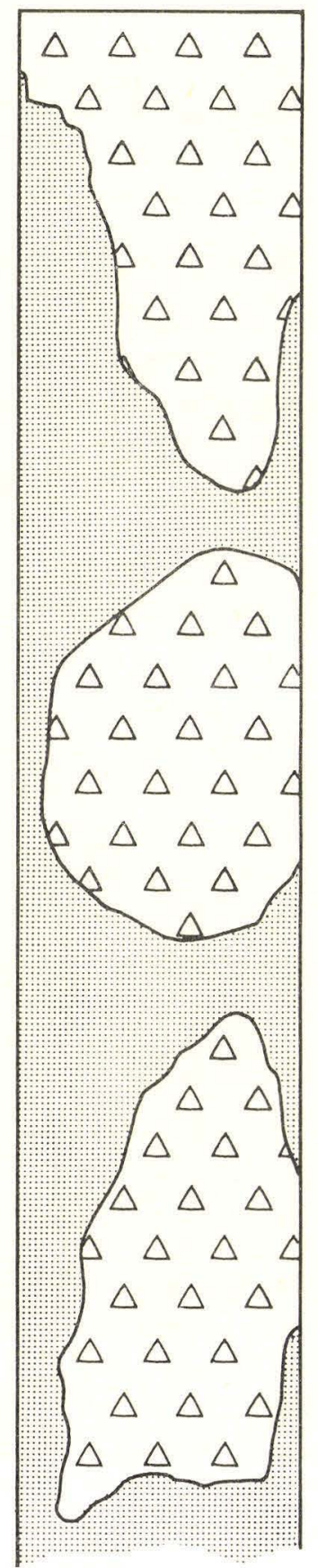

b.

Fig. 2. 
Fig. 2. a) Kerneprøve fra boring nr. 134 i Storebælt, 222-246 cm under havbunden, $19 \mathrm{~m}$ vanddybde. Kernens diameter $4.0-4.5 \mathrm{~cm}$, længde $24 \mathrm{~cm}$ (ca. $3 / 4$ nat. st.). b) Skitse af samme kernestykke, visende tre storre klumper af uomdannet mormeler, mellemlejret af en grødet masse af sandet og stenet ler med gytje og skalfragmenter, udgørende moræneler $\mathrm{i}$ omdannelse til marint sand.

Boring 134, Storebælt, depth $19 \mathrm{~m}$. Core 222$246 \mathrm{~cm}$ below sea-floor. - In the core three boulders of Glacial till are seen, embedded in a marine sediment consisting of disintegrating till, small pebbles, sand and fragments of mollusea.

Fig. 3. Kærneprove fra boring nr. 159 i Storebælt, 5-111 cm under havbunden, $47 \mathrm{~m}$ vanddybde. - Under normalt marint sand (lyst) ses $78 \mathrm{~cm}$ omlejret, morænelers-agtig masse, gruset og stenet, med stumper af molluskskaller og balaner; $98 \mathrm{~cm}$ under havbunden en hel skal af østers (ca. $1 / 3$ nat. st.).

Boring 159, Storebalt, depth $47 \mathrm{~m}$. Core 5-111 $\mathrm{cm}$ below sea-floor. Interval $13-33 \mathrm{~cm}$ normal marine sand (light), 33-111 cm a re-deposited sediment of disintegrating till with sand, gravel, pebbels and fragments of mollusca; at $98 \mathrm{~cm}$ a complete shell of Ostrea edulis.

c

top

15

('m)

5

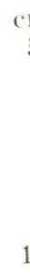

3
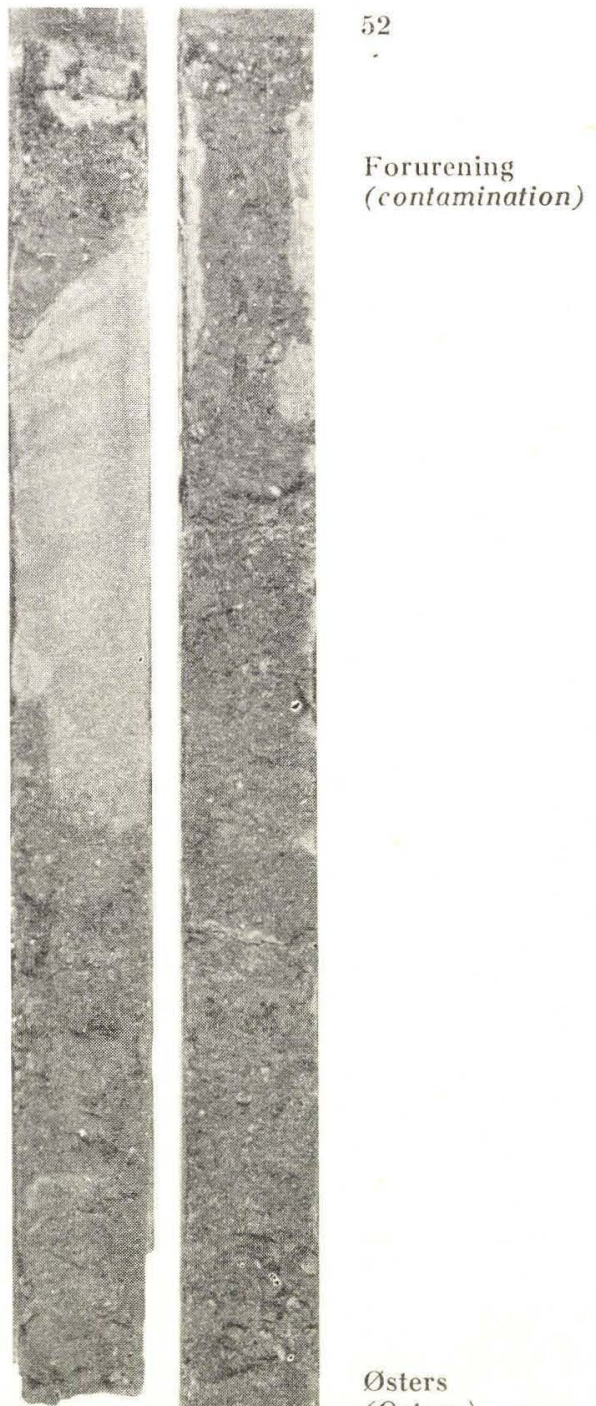

Osters

(Ostrea)

bund (bottom) 
ca. 215- $220 \mathrm{~cm}$ : ler, blågråt, stærkt sandet; både overgrænse og undergrænse ganske uregelmæssige.

220-ca. 265 - : moræneler, lysegråt, stærkt sandet og lidt småstenet, med mange små bløde kridtbrokker; enkelte mørkere grå, uregelmæssige bånd eller pletter af gytje, især omkring 229 og ca. 236$237 \mathrm{~cm}$. Ved $245 \mathrm{~cm}$ en molluskskal.

Fig. 2 a og b.

159. Position r $\varnothing$ d C 11.51 - grøn B 37.11. Vanddybde $47 \mathrm{~m}$.

I den dybe rende ca. $5 \mathrm{~km} \mathrm{~V} \mathrm{t.} \mathrm{S} \mathrm{for} \mathrm{Røsnæs} \mathrm{Fyr.} \mathrm{-} \mathrm{17/9} 1957$.

Efter beskrivelse af hjembragt kerne (jæunfør fig. 3 ).

0-ca. $8 \mathrm{~cm}$ : sand, fint til mellemkornet, marint med skalstumper.

ca. 8-ca. 13 - : ler, gruset, blågråt, med skalstumper (muligvis moræneler under omdannelse til marint sand).

ca. 13-ca. 33 - : sand, fint, gulbrunt, marint.

ca. 33-ca.116 - : ler, gråblåt, gruset og stenet, talrige skalstumper og balaner. Ved ca. $98 \mathrm{~cm}$ skal af $\varnothing$ sters. - Leret har nogen lighed - i altfald $i$ farve og konsistens - med moræneler og er rimeligvis forhenværende moræneler, stedt i omdannelse til marint sand. Der kan dog ikke udskilles egentlige - selv små - klumper af rent moræneler.

Foruden på disse 8 observationspunkter, hvorfra den lagfølge, det lykkedes at fá op som kærner i Kullenbergboret, er beskrevet ovenfor, observeredes på 8 andre borepunkter i Storebælt (og ved Sams $\varnothing$ ) aflejringer af sandet eller gruset ler, der endnu havde bevaret præget af moræneler, men samtidig indeholdt stumper af marine skaller. Veksellejring med mere normale marine sand- eller gruslag blev dog ikke konstateret i kærnerne fra disse sidste 8 borepunkter (nr. 115, 117, 122, 144, 145, 162, 163 og 174); deres geografiske beliggenhed fremgår af kortet over Storebælt (fig. 4).

Disse specielle aflejringer, der bâde vidner om en sæeregen form for erosion og en ligeså særegen form for afsætning, er altså i den nordlige del af Storebælt (og Sams $\varnothing$ Bælt), fra Knudshoved-Halsskov i syd til Sejr $\phi-N o r d s a m s \phi$ i nord, iagttaget på i alt 16 af de ca. 120 borepunkter, der i årene 1953-1959 anbragtes i dette område.

Fig. 4. Lokaliteter i Storebælt med omlejrede lerblokke. Udsnit af søkort nr. 180 (1:470.000), her formindsket til ca. 1:660.000. Dybdekurverne er $10 \mathrm{~m}$ og $30 \mathrm{~m}$. Localities in Storebælt with re-deposited clay-boulders. 


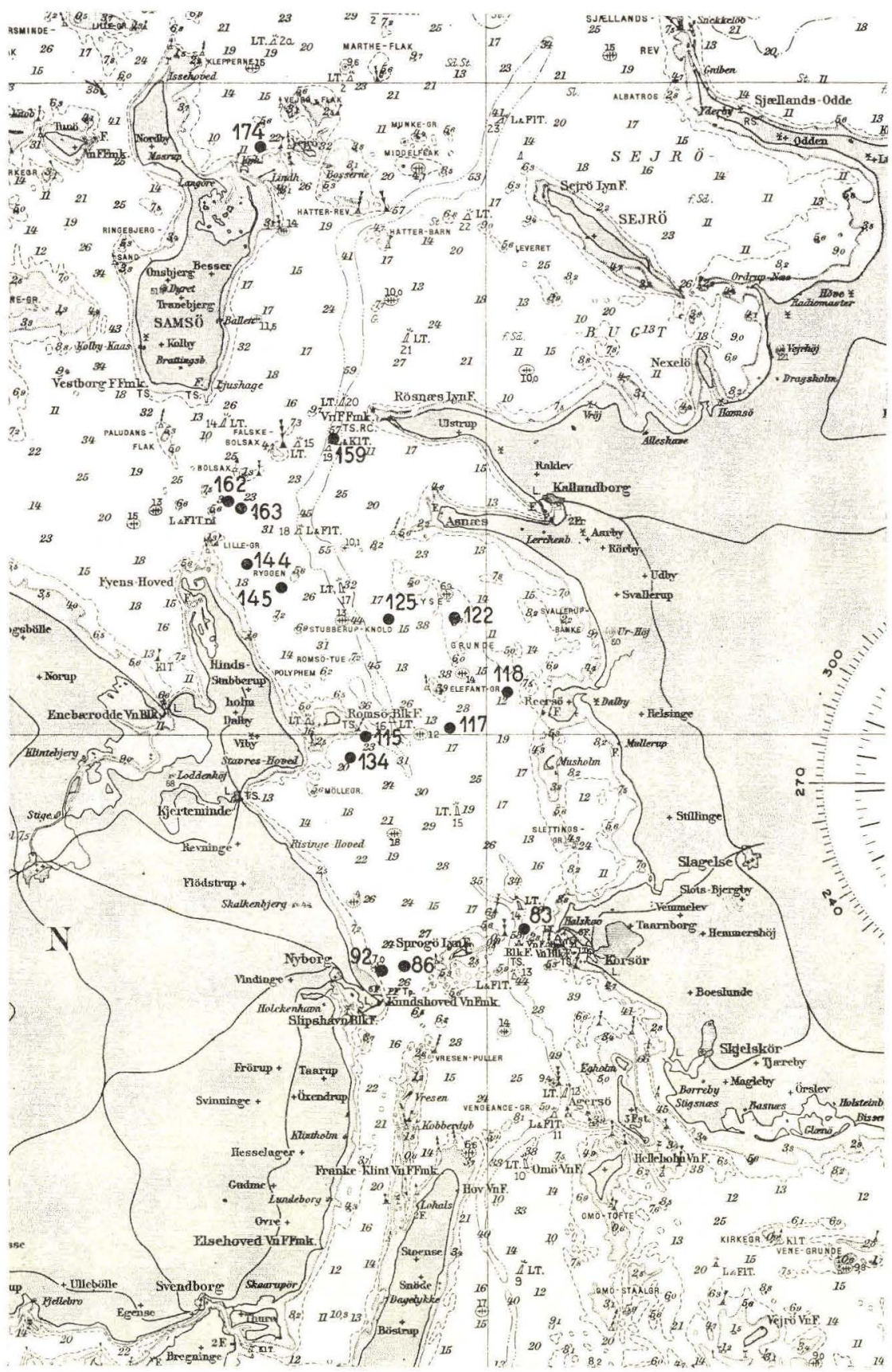




\section{Øresund.}

I 1955 lod »den tekniske Expertgruppe « udf $\varnothing$ re unders $\varnothing$ gelser i Øresund med henblik på et evt. broprojekt Helsing $\varnothing$ r-Hälsingborg. De geologiske undersøgelser - med Kullenbergs bor - forestodes af statsgeolog, fil. dr. Carl Caldenius, Sveriges geologiska undersökning, og prof. B. KullenBERG, Göteborg. Fra dansk side overværedes en del af arbejdet af afdelingsgeolog E.L. Mertz, Harald Krog og Ødum, og ved venlighed fra dr. CaLDENIUS' side har vi fảet tilladelse til at anvende hans observationer herfra.

Brolinjen P. 6. Pos. $56^{\circ} 03^{\prime}, 81-12^{\circ} 37^{\prime}, 6$. Vanddybde 33 m. - 30/8 1955 . 0 -ca. $22 \mathrm{~cm}$ : leret skalsand, rigeligt med skaller.

ca. 22-ca. 80 - : ler, meget fast og tørt (fedt og næsten stenfrit) t $\emptyset \mathrm{r}-$ skorpeagtigt; enkelte gruskorn og småsten.

ca. 80-ca. 120 - : ler med rigeligt af tynde skaller, sten op til $2 \mathrm{~cm}$. ca. 120

Laget ca. 80-120 cm har karakter af rullede morænelersklumper, meget rigt på skalstumper; nederste del af kernen bestod af skalgrus med små morænelersklumper.

Brolinjen P. 7. - samme position og vanddybde.

0-16 $\mathrm{cm}$ : noget leret sand.

16-19 - : lag - muligvis rulleblok - af meget fast, tørskorpeagtigt ler.

19-38 - : ler, rigeligt med skaller.

$38-47$ - : lysegrăt ler, fast, tørskorpeagtigt.

47-54 - : ler med skalfragmenter.

54-75 - : sandet, skalf $\varnothing$ rende mo, nedadtil leret.

75-87 - : ler, mørkt, fast, med Nucula; sandsynligvis interglacialt.

Såvel i »brolinjen « som i den projekterede »tunnellinje» udførtes en lang række boringer til indtil $5 \mathrm{~m}$ dybde i bunden, og adskillige af dem viste en lignende veksling mellem utvivlsomme marine aflejringer, sand og grus (sandsynligvis smeltevandsaflejringer), moræneler med sten og interglacialt marint ler med skaller (ganske stemmende med det interglaciale ler, der bl. a. kendes fra Ven (Øрuм 1933)). 


\section{Strømsedimentets opståen}

Der kan være grund til at understrege, at alle ovenfor meddelte uddrag af dagbøger og journaler fremtræder umiddelbart, som de er noteret i observations $\varnothing$ jeblikket.

Sigurd Hansens observationer fra Lillebælt er så udførlige, at der ikke kan råde tvivl om rigtigheden af den givne forklaring på bundkonglomeratet af lerblokke: det er str $\emptyset \mathrm{mrullede}$ blokke.

Af iagttagelserne fremgår yderligere, at transporten og aflejringen af lerblokkene må være sket for nylig, geologisk set »i dag«; det må altså antages, at løsbrydningen, transporten og aflejringen af lerblokkene er noget, der stadig finder sted. Ved hvilken strømstyrke alt dette sker, lader sig ikke uden videre fastslå, men det må antages, at styrken af bundstrømmen i Lillebælt i hvert fald lejlighedsvis og stedvis overstiger de målte strømstyrker ikke uvæsentligt.

Vender vi os dernæst til Storebælt, så har vi her hidtil op til 16 observationspunkter i modsætning til det ene i Lillebæltsbroens pille, men må til gengæld nøjes med sparsomme og ofte for korte borekerner, mens vi i Lillebælt har haft et åbent og frit tilgængeligt profil til rådighed. I een henseende er der stor forskel på forholdene i de to bælter, nemlig angående materialet i lerblokkene og den faste bund, hvorfra blokkene er taget; i Lillebælt er der kun tale om lillebæltsler (det eocæne Plastiske Ler), medens der i Storebælt kun er tale om istidens moræneler. Så meget des mere påfaldende er det, at sammenligning af iagttagelserne i de to bælter uundgåeligt fører til den slutning, at erosionen, transporten af blokkene og aflejringen af dem i »bundkonglomeratet « er foregået på meget nær overensstemmende måde. De for lillebæltslerets vedkommende iagttagne borerørsudfyldninger af sand har vi dog ikke fundet noget modsvarende til i Storebælts moræneler, hverken i det faste moræneler eller i de omlejrede lerklumper.

Forskellen i materiale $\mathrm{i}$ de to områder bevirker dog også andre forskelle. I Lillebælt må det forurenende sand mellem lerblokkene og de spredte sten tænkes hidført fra bæltets kyster eller steder af bæltets bund, hvor der er kvartære eller tertiære sandede aflejringer, da det overordentlig rene ler, som lillebæltsleret består af, ikke indeholder sand. Anderledes er det i Storebælt; her vil sand-og gruslag mellem lerblokkene nok kunne tænkes at hidrore fra sandede og grusede kvartære aflejringer ved 
bæltets strande og kystklinter, men også fra lignende aflejringer i de højere opragende grunde i bæltet. Der er ydermere den mulighed, at det marine skalførende sand mellem eller over lerklumperne er opstảet ved »opblødning « og opløsning af morænelers-knoldene, således at det marine materiale kan betegnes som et derivat af moræneler, der efterhånden kan omdannes til regulært marint sand eller grus, i hvert fald i de tilfælde, hvor hele bunken af lerblokke påny flyttes ved småændringer i bundstrømmens styrke og retning. Sådanne efterfølgende omlejringer af det særegne bundsediment, som ophobningerne af lerblokke udgør, har vi ganske vist ingen vidnesbyrd om fra Storebælt, men i analogi med forholdene i Lillebælt tør man antage, at de finder sted.

Marint sand og grus vil normalt blive opfattet som opstået ad to veje: 1) direkte tilf $\varnothing$ rsel af sand og grus ved vandløb, eller 2) ved bølgers og overfladestrømmes påvirkning af kysterne og højt opragende grunde, med erosion og efterfølgende sortering af materialet. De her refererede iagttagelser viser os en tredje oprindelsesmåde ved bundstrømme, der i Storebælt arbejder ned til 60-70 m dybde. Strømmen kan enten umiddelbart udsortere sand og grus ved erosion i bundens morænemateriale (mens lerslammet føres bort til roligere steder), eller sand og grus kan opstå mere indirekte gennem stadier med lerblokke som del af et bundkonglomerat, der måske omlejres flere gange, inden materialet helt omdannes til marint sand og grus af normalt præg.

Denne tredje oprindelsesmåde for marint sand og grus er naturligvis ikke helt ny og ukendt. Det er således klart, at de dybe, tidevandseroderede render mellem de vestslesvigske øer også må levere marint sand og finsand fra bunderosion i $20-40 \mathrm{~m}$ dybde, men et mellemtrin i udviklingen, svarende til lerblokkene i bælterne, er os dog ikke bekendt fra disse vestslesvigske render.

Det omtalte overgangstrin mellem moræneler i opløsning og marint sand er afbildet i fig. 2-3; det ses dels i 2 a og 2 b som mellemmassen mellem de endnu kompakte morænelersklumper, dels i 3, hvor hele den $106 \mathrm{~cm}$ lange kerne (på nær $20 \mathrm{~cm}$ velsorteret sand) består af en sådan overgangsdannelse, hvor meget af morænelers-strukturen og lerindholdet er bevaret, mens der på den anden side optræder mange skalstumper og endog - $98 \mathrm{~cm}$ under havbunden - en hel skal af $\emptyset$ sters. De på kortet over Storebælt afmærkede observationssteder markerer altså dels findesteder for typisk lerblokkonglomerat (som i fig. 2 a-b), dels sådanne for overgangsdannelsen (som i fig. 3).

De ca. 120 observationer i det nordlige Storebælt og Samsøbælt, som D. G. U. har udført i årene 1953-59, har givet os et ganske godt generelt billede af bundaflejringerne i dette farvand. Endnu er det dog formentlig for tidligt at tegne detaillerede kort over disse bundaflejringers udbredelse.

Nøgen, fast bund af istidsdannelser, vel mest moræneler, findes adskillige steder i de dybeste render og i strømsnævringer som $\emptyset$ st og vest om Sprogø, dog også på de omgivende plateauer. Disse områder er naturligvis underkastet erosion af nutidige bundstrømme, og de leverer sandsynligvis materiale af lerblokke til naboområder med bundkonglomerat af sådanne 


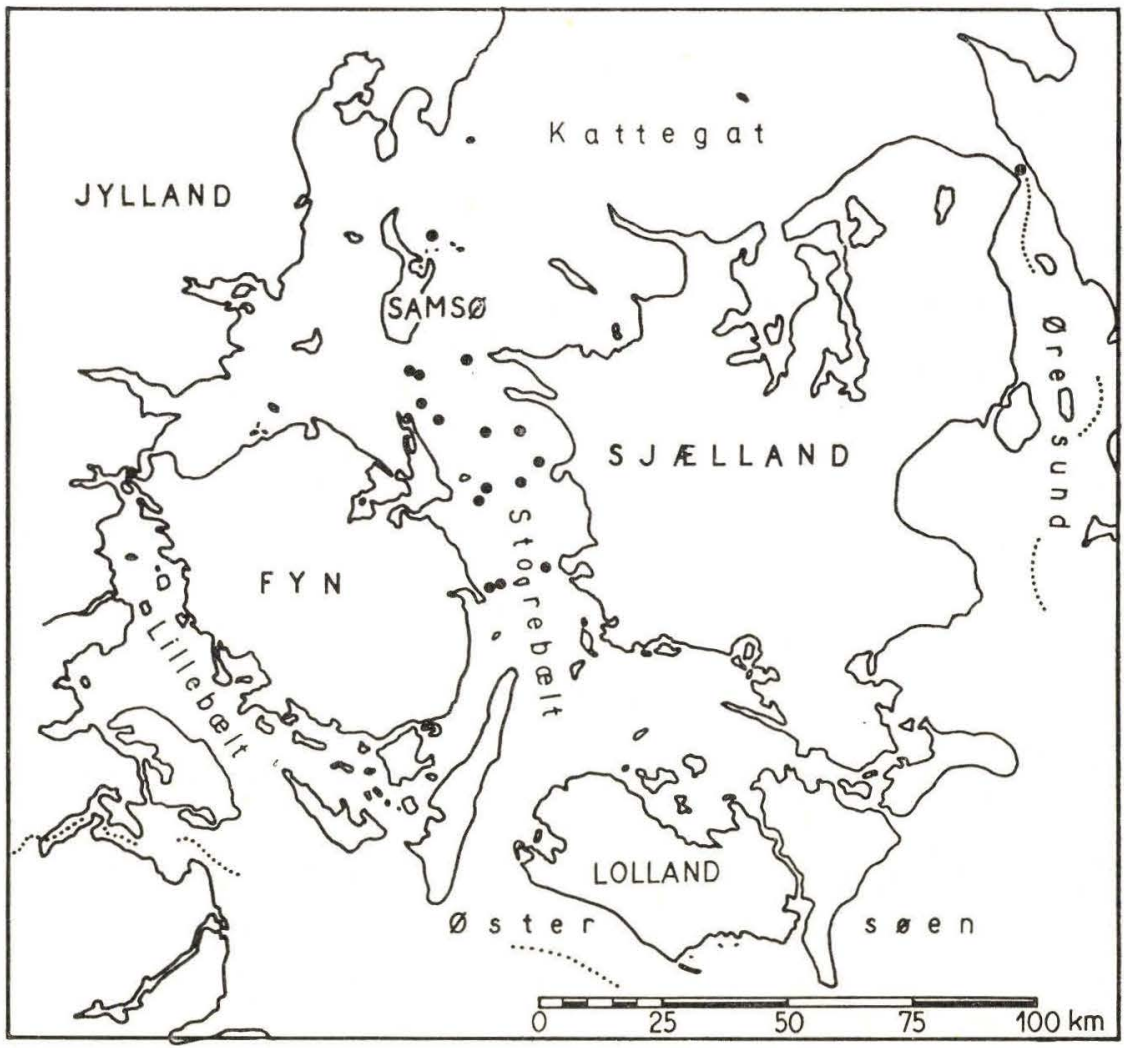

Fig. 5. Observationspunkter for strømrullede lerblokke i danske farvande.

Localities where rolled boulders of clay occur as bottom deposit in Danish Waters: Lillebælt, Storebalt and The Sound (Øresund).

blokke. Størstedelen af arealerne med nøgen, fast bund har dog en tynd - sikkert vandrende og skiftende - belægning af groft sand og sten.

Konglomeratet af lerblokke og overgangsdannelsen dækker sikkert flere snese eller hundreder af $\mathrm{km}^{2}$ i området. Omridset af udbredelsen kan dog ikke indtegnes på kort på basis af de 16 forekomster, men et blik på kortet fig. 4 giver dog et indtryk af udbredelsen. De næunte dannelser forekommer dels i renderne ( $\mathrm{nr} .83 \mathrm{c}-29,5 \mathrm{~m}$; $\mathrm{nr} .83 \mathrm{~b}-31 \mathrm{~m}$; nr. 86 a $-27,5$ m; nr. $162-34,5$ m; nr. $163-33$ m; nr. $159-47$ m), dels på skråningerne ned mod renderne (nr. $92-24,5 \mathrm{~m}$; nr. $115-22,5 \mathrm{~m}$ ) og endelig i adskillige tilfalde på de jævnere plateauer mellem renderne og i ret stor afstand fra disse (nr. $117-16,5 \mathrm{~m}$; nr. $118-13,5 \mathrm{~m}$; nr. 125 - 18 m; nr. $134-19$ m; nr. $144-22,5$ m; nr. $174-12,5$ m). Den højest beliggende konstaterede forekomst er nr. 122 på kun $8,25 \mathrm{~m}$ vanddybde. Da S/S »Biologen « og Kullenbergs udstyr ikke har kunnet arbejde på lavere vand end 7-8 $\mathrm{m}$, har vi ikke kunnet iagttage disse særlige bund- 
sedimenter på lavt vand. I de mere åbne partier af farvandet synes bundformen på de lavere vanddybder dog at være tykke lag af normalt marint sand (og grus).

Flertallet af de ca. 120-130 iagttagelser indenfor området har dog vist tykke aflejringer af marint ler og gytje (cardium-ler og-gytje) som bundform, og dette gælder såvel mere beskyttede farvande som Kerteminde Bugt som også meget udstrakte partier af de mere åbent og frit beliggende områder, deriblandt også de største dele af plateau-områderne mellem renderne. På sådanne områder eftersøgte vi med ekkoloddet flade bassiner, der ved at vise »dobbelt bund « i ekkogrammet gav håb om forekomsten af mere udviklede, postglaciale lagserier (udredelsen af disse farvandes historie er arbejdets hovedmål).

De bløde ler- og gytjeaflejringer er foruden på de to nævnte arter af områder (beskyttede bugter og jævne plateauer) dog også på et par punkter påvist i de dybe rendepartier (nr. $124-39 \mathrm{~m}$ og nr. $136-36 \mathrm{~m}$ ), hvor der blev truffet henholdsvis $3,6 \mathrm{og} 6,2 \mathrm{~m}$ bl $\varnothing$ de lag af ler, lergytje og gytje, uden at fastere bund nảedes på disse to punkter. De pågældende rendepartier er beliggende SV og $\mathrm{S}$ for Lysegrunde i Jammerland Bugt. Disse mere isolerede rendestykker synes således at være underkastet stærk sedimentation i nyere tid, og de her beskrevne strømfænomener gør sig altså ikke gældende i dem.

Man kunne spørge efter profiler med konglomerat af lerblokke under tykkere lag af bløde ler- og gytjeaflejringer, men svigtende teknik ved Kullenbergborets anvendelse har hidtil hindret os $\mathrm{i}$ at påvise sådanne (se dog bor. 134); de ville ellers i sig selv være vidne om de beskrevne processers optræden i den ældre del af den marine periode. De beskrevne profiler bærer alle præg af, at erosionsprocessen og aflejringen af lerblokkene er foregået i recent eller alleryngste postglaciale tid; i Lillebælt synes der især at yære tale om helt nutidige processer. Først i de seneste år har der åbnet sig en mulighed for helt præcise aldersbestemmelser ved anvendelse af molluskskallerne mellem lerblokkene til $\mathrm{C}_{14}$-dateringer, men sådanne bestemmelser er endnu ikke gennemførte.

Tolkningerne fra Storebælt kan også overføres til boreprofilerne fra $\emptyset$ resund. Her optræder ikke alene moræneler som rulleblokke, men også det interglaciale, fossilførende ler, der kendes fra klinterne på Ven. Der er dog ingen tvingende grund til at antage så lang en transportvej som fra Ven til Lappegrund for disse lerblokke; det omhandlede ler kan godt være faststående på havbunden mellem de to nævnte lokaliteter. - Også dr. Caldenius slutter sig til den tolkning, at det drejer sig om strømtransporterede blokke: „På moränleran innehöllo nämligen sandens bottenlager bollar av moränlera, rester av block av moränlera, som av strömmen skurits ut ur fåror i bottnen. . . . Förutom de redan nämnda lerbollarna, vars diameter synes kunna uppgå till $0,5 \mathrm{~m}$ eller mera, innehållar sanden gyttjeartade skikt, mjäla- och moskikt i oregelbunden växling med grövre material sand, grus och block samt här och var slagg och andra avfallsprodukter. Med den starka ström, som tidtals är rådande i sundet, äro sannolikt stora partier av ytsanden ständigt på drift« (rapport af 3 . december 1955 til »Tekniska Expertgruppen«). 


\section{Bemærkninger om farvandenes submarine morfologi}

Den submarine morfologi af Øresund og de to bælter - de tre vigtige indgangsporte til Østersøen - og da særlig genesen af de dybe render har for år tilbage været stærkt diskuteret i den skandinaviske geologiske litteratur (V. Hintze, P. Harder, Ernst Antevs, V. Milthers, Knud Jessen, L. von Post), den væsentligste litteratur er anført hos S. A. ANDERSEN 1927 og H. Munthe 1940.

Diskussionernes hovedemner, der dels var »Den nordeuropæiske Fastlandstid«, dels Østersøens særlige forhold i den senglaciale tid og Ancylustiden (»inland Sea» eller »fresh-water Lake») skal vi ikke her komme ind på, men blot fremhæve, at de dybe og ofte ret smalle render i vore bælter og sunde har været tolkede som 1) tektonisk betingede, eller eroderede af 2) subglaciale smeltevandsstrømme, 3) ekstramarginale smeltevandsstrømme, 4) fastlandstidens ferskvandsfloder (»Dana Älv«), eller 5) marine bundstrømme i Litorinatiden (eventuelt tidevandsbetonede) og i postlitorinal-recent tid.

D. G. U.'s maringeologiske undersøgelser i Storebælt har endnu ikke givet os materiale nok til fuldt ud at kunne vurdere disse forskellige tolkninger for dette bælts vedkommende. Foreløbigt er det vort indtryk, at formodentlig alle de 4 sidstnævnte erosionsformer har været medvirkende for forskellige afsnit af renderne. Udelukket er det ikke, at et og samme rendestykke kan have været underkastet 2-4 af de nævnte erosionsformer og da i den nævnte tidsmæssige rækkef $\varnothing$ lge. Vore iagttagelser over bundstrømmes erosion og aflejringer af lerblok-konglomeratet leder naturligvis fortrinsvis opmærksomheden hen på den sidste af de nævnte erosionsmuligheder, den marine bunderosion. Denne erosionsmulighed har særlig S. A. Andersen (1927) peget på, idet han specielt fremhæver, at de dybeste »huller « i renderne fortrinsvis findes, hvor passagen er snævrest, f. eks. hvor de forskellige subakvatiske rygge eller rækker af grunde, der jo oftest tolkes som submarine randmoræner, krydser bæltet. Ligeledes peger Andersen på paralleliteten med de tidevandseroderede »dyb eller rendeformede huller mellem øerne i det slesvigske vadehav. Den langt kraftigere vandudveksling gennem bælterne og sundet i Litorinatiden, formentlig betinget af kraftigere ud- og indgående tidevandsstrømme, der gjorde Østersøen mere salt, så østersen kunne trives ved Holstens $\phi$ stkyst, har Stemann Niflsen (1939) diskuteret udf $\varnothing$ rligt. 
Vi må derfor afvente endnu flere og mere detaillerede maringeologiske undersøgelser i Storebæltsområdet, inden vi kan påvise rendestykker, der med sikkerhed kan betegnes som restpartier af lejet for den mægtige flod, som efter von Post (1929) må have dannet afløbet for Østersøens ferske vandmasse $\mathrm{i}$ den senere del af Ancylustiden, og som han har navngivet som »Dana Älv«. Såvel senere marin sedimentation, som påvist i rendestykkerne tæt SV for Lysegrund, og den i nærværende afhandling skildrede strømerosion har bidraget stærkt til at omforme de bevarede stykker af dette eventuelle flodafl $\varnothing$ b.

\section{Litteratur}

Andersen, S. A., 1927: Storebælt i nutid og fortid. Geologiska Fören. i Stockholm Förhandlingar. Bd. 49, s. 427. Stockholm.

Brannov, Svend, 1925: Forundersøgelser for Lillebæltsbroen 1923-24. Ingeniøren XXXIV, nr. 4, s. 37-47. 1925. København.

D. S. B., 1935: Lillebæltsbroen. De Danske Statsbaner. 14. maj 1935. København.

Hintze, V., 1908: Den nordeuropæiske Fastlandstid. Meddelelser fra Dansk Geologisk Forening. Bd. 3, s. 169. København.

HuUlström, Filip, 1935: Studies of the morphological activity of rivers as illustrated by the River Fyris. Bull. of the Geol. Institution of the University of Upsala. Vol. XXV, s. 221. Upsala.

JACOBSEN, J. P., 1925: Die Wasserumzetzung durch den Öresund, den Grossen und den Kleinen Belt. Medd. fra Komm. for Havundersøgelser. Serie Hydrografi. Bind II, Nr. 9. København.

Jessen, Knud, 1926: Lillebelt i Senglacialtiden. Geol. Fören. i Stockholm Förh. Bd. 48, s. 127. Stockholm.

Kommissionen angående en Storebæltsbro. Betænkning nr. 155. 1956.

- Betænkning nr. 237. 1960.

Kullenberg, B., 1947: The Piston Core Sampler. Svenska Hydrografisk-Biologiska Kommissionens Skrifter. Tredie Serien: Hydrografi, Bd. 1, Häfte 2. Göteborg.

- 1945: Nya svenska profillod. Medd. fra Dansk Geol. Forening. Bd. 10, s. 557. København.

Meteorologisk Institut. Nautisk-Meteorologisk Årbog. København.

Munthe, Henr., 1940: Om Nordens, främst Baltikums, senkvartära Utveckling och Stenåldersbebyggelse. Kungl. Svenska Vetenskapsakademiens Handlingar. Tredje Serien. Bd. 19. Nr. 1. Stockholm.

Nielsen, E. Steemann, 1938: De danske farvandes hydrografi i Litorinatiden. Medd. fra Dansk Geol. Forening. Bd. 9., s. 337. København.

von Post, Lennart, 1929: Svea, Göta och Dana Älvar. »Ymer«. Årg. 1929. Häfte 1. Stockholm.

Øрuм, H., 1933: Marint Interglacial paa Sjælland, Hven, Møn og Rügen. Danmarks Geol. Undersøgelse. IV. R. Bd. 2. Nr. 10. København.

- 1951: En fælles dansk-svensk undersøgelse af Østersøområdets sen- og postglaciale sedimenter. Medd. fra Dansk Geol. Forening, bd. 12, hft. 1. s. 175. København. 